\title{
Epidemiology of Acute Respiratory Failure and Mechanical Ventilation
}

\author{
H.S. SURI, G. LI, and O. GAJIC
}

\section{Introduction}

Acute respiratory failure, and the need for mechanical ventilation, remains one of the most common reasons for admission to the intensive care unit (ICU). The burden of acute respiratory failure is high in terms of mortality and morbidity as well as the cost of its principal treatment, mechanical ventilation. Very few epidemiologic studies have evaluated the prevalence and outcome of acute respiratory failure and mechanical ventilation in general. Most of the published literature has focused on specific forms of acute respiratory failure, particularly acute lung injury (ALI) and acute respiratory distress syndrome (ARDS). In this chapter, we provide a brief review of the pathophysiology of acute respiratory failure, its definition and classification, and then present the incidence and outcomes of specific forms of acute respiratory failure from epidemiologic studies.

\section{Definition and Classification}

Normal respiration requires the integrated function of several components of the respiratory system (Fig. 1). Dysfunction of any component results in the impairment of normal gas exchange and may lead to acute respiratory failure and the need for mechanical ventilation. According to the underlying pathophysiologic mechanism, acute respiratory failure is usually divided into four patterns: Types I-IV (Table 1). Type I and type II respiratory failure are also referred to as hypoxemic and hyper-

Fig. 1. Vital components of the respiratory system

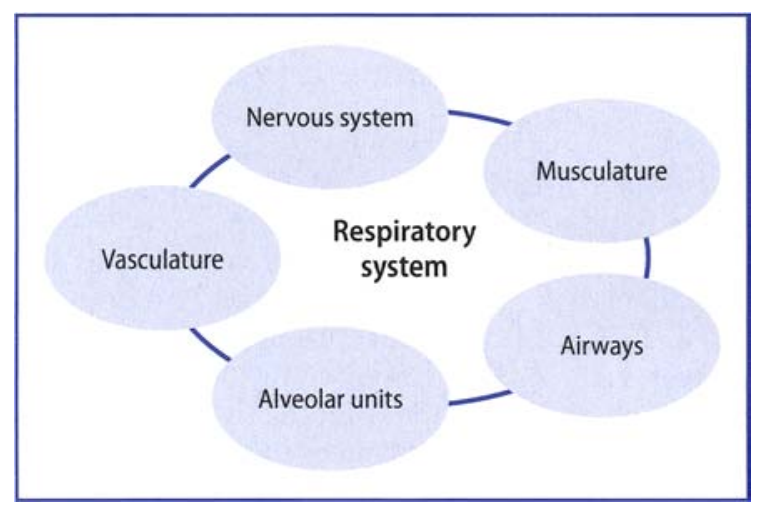


Table 1. Pathophysiological classification of acute respiratory failure with corresponding clinical syndromes.

\begin{tabular}{|c|c|c|c|c|}
\hline & Type I & Type II & Type III & Type IV \\
\hline Mechanism & $\begin{array}{l}\text { V/Q mismatch } \\
\text { Shunt (Qs/Qt) }\end{array}$ & Alveolar hypoventilation & $\begin{array}{l}\text { Atelectasis } \\
\text { Shunt (Qs/Qt) }\end{array}$ & $\begin{array}{l}\text { Hypoperfusion } \\
\text { Metabolic acidosis }\end{array}$ \\
\hline $\begin{array}{l}\text { Anatomic } \\
\text { components }\end{array}$ & $\begin{array}{l}\text { Alveolar unit failure } \\
\text { Pulmonary vascular } \\
\text { failure }\end{array}$ & $\begin{array}{l}\text { CNS dysfunction } \\
\text { Neuromuscular failure } \\
\text { Airway dysfunction }\end{array}$ & $\begin{array}{l}\text { Regional alveo- } \\
\text { lar unit collapse }\end{array}$ & $\begin{array}{l}\text { All tissues } \\
\text { Respiratory muscles }\end{array}$ \\
\hline $\begin{array}{l}\text { Clinical } \\
\text { syndromes }\end{array}$ & $\begin{array}{l}\text { Pulmonary edema } \\
\quad \text { ALI, CPE } \\
\text { Pneumonia } \\
\text { Trauma } \\
\text { ILD* }\end{array}$ & $\begin{array}{l}\text { Coma } \\
\text { NMD* }^{*} \\
\text { COPD*,** }^{*} \\
\text { Asthma }\end{array}$ & Perioperative & Shock \\
\hline
\end{tabular}

* may occur as acute exacerbations - acute on chronic respiratory failure;

${ }^{* *}$ type I and type II respiratory failure frequently co-exist; ILD: interstitial lung disease; NMD: neuromuscular disorder; COPD: chronic obstructive pulmonary disease; ALI: acute lung injury; CPE: cardiogenic pulmonary edema; CNS: central nervous system

capnic respiratory failure, based on a predominant gas exchange abnormality. In many disease states however, more than one pathophysiologic mechanism is operational and clinical criteria that incorporate setting, acuity, and severity are used more often (Table 1). Acute episodes (exacerbations) of respiratory failure in patients with chronic compensated respiratory insufficiency are usually referred to as 'acute on chronic' respiratory failure.

A consensus definition of acute respiratory failure is not available and most studies have used the combination of mechanical ventilation (of variable duration) with or without evidence of severe hypoxemia on arterial blood gas analysis. While some studies utilized a more strict definition than others, the essential component in all has been the need for mechanical ventilation. The indications for mechanical ventilation, however, are mostly based on clinical observations (increased respiratory rate, use of accessory muscles, paradoxical chest wall movements, changes in mental state), none of which has sufficient accuracy or precision. Therefore, the epidemiology of acute respiratory failure has so far been restricted to 'treated' acute respiratory failure, possibly explaining the wide variations in the reported incidence and outcomes of acute respiratory failure and associated clinical syndromes. Since the availability of intensive care and mechanical ventilation vary greatly in different parts of the world, the burden of acute respiratory failure may be severely underestimated depending on the access to ICU services.

\section{Incidence and Outcome of Acute Respiratory Failure}

The incidence of acute respiratory failure varies according to the definition used and the population studied (Table 2). Two European studies, one conducted in Germany [1] and the other in Sweden, Denmark, and Iceland [2], estimated very similar incidences, 88.6 and 77.6 cases per 100,000 person-years. Both studies used an identical definition (intubation and mechanical ventilation for $>24 \mathrm{~h}$ regardless of arterial blood gas findings) and employed a multicenter approach with large patient cohorts over a short period ( 8 weeks). On the other hand, Behrendt reported a much higher 
Table 2. Comparison of selected epidemiological studies of acute respiratory failure

\begin{tabular}{|c|c|c|c|c|c|c|}
\hline Study & Design & Definition of ARF & $\begin{array}{l}\text { Age of } \\
\text { popula- } \\
\text { tion }\end{array}$ & $\begin{array}{l}\text { Setting, duration } \\
\text { and year of } \\
\text { study }\end{array}$ & Incidence & $\begin{array}{l}\text { Mortal- } \\
\text { ity } \%\end{array}$ \\
\hline $\begin{array}{l}\text { Esteban } \\
{[4]}\end{array}$ & $\begin{array}{l}\text { Prospective } \\
\text { observa- } \\
\text { tional }\end{array}$ & $\begin{array}{l}\text { Need of mechanical } \\
\text { ventilation }>12 \text { hours }\end{array}$ & Adult & $\begin{array}{l}361 \text { International } \\
\text { ICUs, } 1 \text { month, } \\
1998\end{array}$ & $\begin{array}{l}33 \% \text { of ICU } \\
\text { admissions }\end{array}$ & $30.7 \%$ \\
\hline $\begin{array}{l}\text { Vincent } \\
{[7]}\end{array}$ & $\begin{array}{l}\text { Prospective } \\
\text { observatio- } \\
\text { nal }\end{array}$ & $\begin{array}{l}\mathrm{PaO}_{2} / \mathrm{FiO}_{2} \text { ratio }<200 \\
\text { and the need of } \\
\text { mechanical respiratory } \\
\text { support }\end{array}$ & $\begin{array}{l}>12 \\
\text { years }\end{array}$ & $\begin{array}{l}40 \text { International } \\
\text { ICUs, } 1 \text { month, } \\
1995\end{array}$ & $\begin{array}{l}56 \% \text { of ICU } \\
\text { admissions }\end{array}$ & $31 \%$ \\
\hline Luhr [2] & $\begin{array}{l}\text { Prospective } \\
\text { observa- } \\
\text { tional }\end{array}$ & $\begin{array}{l}\text { Intubation and mechan- } \\
\text { ical ventilation } \geq 4 \\
\text { hours regardless of } \mathrm{FiO}_{2}\end{array}$ & $\begin{array}{l}>15 \\
\text { years }\end{array}$ & $\begin{array}{l}\text { Sweden, Den- } \\
\text { mark Iceland } \\
\text { \& Norway, } \\
8 \text { weeks, } 1997\end{array}$ & $\begin{array}{l}77.6 \\
\text { per } 100,000 \\
\text { person-years }\end{array}$ & $41 \%$ \\
\hline $\begin{array}{l}\text { Vasilyev } \\
\text { [38] }\end{array}$ & $\begin{array}{l}\text { Prospective } \\
\text { observa- } \\
\text { tional }\end{array}$ & $\begin{array}{l}\text { Mechanical ventilation } \\
>24 \text { hours and } \mathrm{FiO}_{2} \\
>0.5 \text { for at least } \\
24 \text { hours. }\end{array}$ & All ages & $\begin{array}{l}\text { Multicenter, } \\
2 \text { months } \\
1991-1992\end{array}$ & Not studied & $44.4 \%$ \\
\hline $\begin{array}{l}\text { Lewan- } \\
\text { dowski } \\
\text { [1] }\end{array}$ & $\begin{array}{l}\text { Prospective } \\
\text { Observa- } \\
\text { tional }\end{array}$ & $\begin{array}{l}\text { Intubation and mechan- } \\
\text { ical ventilation } \geq 24 \\
\text { hours regardless of } \mathrm{FiO}_{2}\end{array}$ & $\begin{array}{l}>14 \\
\text { years }\end{array}$ & $\begin{array}{l}\text { Berlin (Germany), } \\
8 \text { weeks, } 1991\end{array}$ & $\begin{array}{l}88.6 \\
\text { per } 100,000 \\
\text { person-years }\end{array}$ & $42.7 \%$ \\
\hline $\begin{array}{l}\text { Behrendt } \\
\text { [3] }\end{array}$ & $\begin{array}{l}\text { Retro- } \\
\text { spective }\end{array}$ & $\begin{array}{l}\text { ICD-9-CM for respiratory } \\
\text { failure and mechanical } \\
\text { ventilation }\end{array}$ & $\begin{array}{l}>5 \\
\text { years }\end{array}$ & $\begin{array}{l}\text { United States, } \\
1 \text { year } 1994\end{array}$ & $\begin{array}{l}137.1 \\
\text { per } 100,000 \\
\text { person-years }\end{array}$ & $35.9 \%$ \\
\hline
\end{tabular}

incidence of acute respiratory failure in the USA, 137.1 per 100,000 patient-years. This incidence was estimated based on the ICD-9-CM disease codes for diagnoses and treatment in patients $>5$ yrs old observed over a 1-year period [3]. The significant variation between the US and European incidences may in part be explained by the differences in study design (Table 2 ) and in part by inconsistent indications and access to mechanical ventilation in different countries.

Acute respiratory failure is often accompanied or followed by a failure of other vital organs, and death most often occurs because of multiorgan failure (MOF) and the withdrawal of mechanical ventilation when the chances for a meaningful recovery of the patient's quality of life are deemed to be exceedingly low. Imprecision of clinical prognostic criteria, variations in available resources, and patient and provider preferences limit the interpretation of mortality data from different epidemiologic studies.

Reported mortality rates for acute respiratory failure from the 1990s are remarkably similar, approximately $40 \%$ in spite of differences in study designs and the definitions applied (Table 2). Lewandowski and coworkers [1] studied 476 patients from 72 ICUs in Berlin, Germany and reported mortality rates of $36-58 \%$ depending on the lung injury score (LIS). In a large prospective study from Scandinavia, Luhr and coworkers reported an all-cause 90 -day mortality of $41 \%$ [2]. In a large, prospective international cohort involving 361 ICUs, Esteban and coworkers reported an ICU mortality of $30.7 \%$. Mortality increased significantly in patients with sepsis, shock, ARDS, or liver failure [4]. Vincent and coworkers used sequential organ failure 
assessment (SOFA) score criteria and the need for mechanical ventilation to define acute respiratory failure and estimated an overall ICU mortality of $31 \%$. The mortality was much lower $(7 \%)$ when the lung was the only organ involved [5]. Recently, Flaatten and coworkers reported the mortality from acute respiratory failure at different time points after disease onset. Mortality was again the lowest in single organ acute respiratory failure and rose with each additional organ failure. Higher mortality rates were found 90 days after the onset compared to at ICU or hospital discharge [6]. MOF following an ICU admission, presence of circulatory shock on ICU admission, older age, and pre-existing comorbidities (cirrhosis, malignancy and chronic renal failure) were independent risk factors for the mortality rate reported in several studies $[4,7-9]$.

\section{Epidemiology of Specific Clinical Syndromes}

\section{Acute Lung Injury (ALI)}

ALI and its more severe form, ARDS, are clinical syndromes defined as an acute onset of hypoxemic respiratory failure with diffuse pulmonary infiltrates in the absence of left atrial hypertension as the principal cause of acute pulmonary edema. ALI is a major cause of acute respiratory failure in the ICU and is associated with high morbidity and mortality. Since it was first described by Ashbaugh and colleagues [10] and than redefined in 1994 [11], there have been significant advances in the understanding of etiology, pathophysiology, and the epidemiology of ALI. Clinical risk factors for ALI are usually divided into direct (pulmonary) and indirect (extrapulmonary). Pneumonia, aspiration, lung contusion; and inhalation injury are the principal pulmonary risk factors, while sepsis, shock, trauma, pancreatitis, and multiple transfusions represent the most important extrapulmonary risk factors. In recent years, transfusion-related ALI (TRALI) and novel viral pathogens (severe acute respiratory syndrome [SARS]) have emerged as important risk factors for ALI.

The reported incidence of ALI has varied significantly. The 1972 report of the National Heart and Lung Institute Task Force on Respiratory Diseases, estimated 150,000 cases of ARDS per year yielding the annual incidence of 75 per 100,000 person-years. Subsequent studies reported an incidence of ALI ranging from 16 to 34 cases per 100,000 person-years in European countries [2,12] and Australia [13], and a much higher incidences of ALI in the USA, 78 per 100,000 persons-years $(190,600$ cases per year) [13-15]. While a significant minority of patients with ALI is treated with non-invasive ventilation (NIV), the majority of studies included only patients treated with invasive ventilation. A recently completed, retrospective, community cohort study in Olmsted County, Minnesota included patients treated with NIV and found an even higher incidence of ALI, 156 per 100,000 person-years (personal communication, Rodrigo Cartin-Ceba).

Mortality from ALI varies greatly depending upon the age of the patient, underlying chronic illnesses, ALI risk factors, and non-pulmonary organ dysfunctions [15]. Two decades ago, the mortality rate from ALI ranged from $50-70 \%[4,8,16,17]$, but has since declined and more recently has been estimated to be about $30-50 \%$ $[2,13,15,23]$. Advances in general supportive care [9] and the use of new mechanical ventilation strategies [16] may account for most of the change.

Both the incidence of and mortality from ALI increase exponentially with age $[1-3,15,18]$. MOF $[7,19,20]$, liver failure, severe sepsis $[8,9,15,17]$, aspiration [15], presence of infection and neurological failure on ICU admission [7], and pree- 
xisting cirrhosis $[2,8,17,21]$, bone marrow transplantation, human immunodeficiency virus (HIV) [17], hematologic [7,22] or active malignancy [17, 22], and Charlson comorbidity score [23] have been associated with a higher mortality. Persistent severe hypoxemia and cardiovascular failure also predict poor outcomes [21, 23].

Non-survivors of ALI die predominantly of MOF. A landmark study published in 1985 reported that only $16 \%$ of deaths were caused by respiratory failure [24]. Similar results ( $16 \%$ and $9 \%)$ were reported by two studies conducted in recent years $[13,25]$. MOF, septic shock, and underlying comorbidities are the most common causes of death in patients with ALI.

Survivors of ALI often have a prolonged recovery and significant short and longterm disability. While lung function usually returns to normal within several months [9], neuromuscular and neurocognitive sequelae may persist much longer $[26,27]$. The most important predictors of prolonged disability are the use of systemic steroids during the ICU stay, presence of a complicating illness acquired during the ICU stay, and the rate of resolution of ALI and MOF [27]. Neuropsychological sequelae are also common and about $27 \%$ of long-term survivors develop posttraumatic stress disorder [28]. With a decline in mortality from ALI, more survivors are at risk of prolonged morbidity ('chronic critical illness') contributing to substantial increases in the utilization of health care resources.

\section{Cardiogenic Pulmonary Edema}

Cardiogenic pulmonary edema is a common cause of acute respiratory failure. In about $10 \%$ of the mechanically ventilated patients in an international cohort study, cardiogenic pulmonary edema was the principal reason for instituting mechanical ventilation [4]. Other epidemiologic studies reported similar rates of cardiogenic pulmonary edema $[2,29]$ with mortality ranging from $28-48 \%[1,4]$. In the past two decades, NIV, both continuous positive airway pressure (CPAP) and bilevel positive airway pressure (BiPAP) ventilation, have received a great deal of interest in the management of patients presenting with acute cardiogenic pulmonary edema. Randomized trials comparing either CPAP or BiPAP with standard medical therapy, found similar improvements in arterial blood gases and breathing rates, reduced need for intubation, and improved outcome [30].

\section{Acute Exacerbation of Chronic Obstructive Pulmonary Disease}

According to the World Health Organization, chronic obstructive pulmonary disease (COPD) ranks fourth among all causes of death with an age-adjusted mortality rate of 39.9 per 100,000 person-years. The $20^{\text {th }}$ century pandemic of cigarette smoking is taking its toll, evident by the increase in the annual hospitalization rate for acute exacerbation of COPD from 9.7 in 1988 to $24.4 \%$ in 2005 . Moreover, about $10 \%$ of all hospitalizations are directly or indirectly attributable to COPD [31]. Many patients with acute exacerbation of COPD require admission to the ICU for acute respiratory failure. In an international cohort study [4], acute exacerbation of COPD was a principal indication for initiating mechanical ventilation in $13 \%$ of patients with acute respiratory failure.

The hospital mortality rate of COPD patients admitted with acute exacerbation varies between $2.5-30 \%$, depending on the methodology of the data collection and the patient population. Seneff et al. [32] reported a hospital mortality rate of $24 \%$ 
in 362 admissions for acute exacerbation of COPD selected from the acute physiology chronic health evaluation (APACHE) III database of 17,440 admissions in a prospective multicenter trial. Mortalities rose to $30 \%$ at hospital discharge and doubled to $59 \%$ at the 1-year follow-up. Invasive mechanical ventilation was instituted in 170 of 362 patients with a mortality rate of $47 \%$. After controlling for the severity of illness, mechanical ventilation at ICU admission was not associated with either hospital mortality or subsequent survival. Development of non-respiratory organ dysfunction was the most important predictor of hospital mortality, while the abnormalities in gas exchange $\left(\mathrm{PaCO}_{2}, \mathrm{pH}, \mathrm{PaO}_{2}\right)$ indicative of advanced dysfunction were strongly associated with six month mortality.

Esteban et al. [4] reported a hospital mortality of $28 \%$ in patients receiving mechanical ventilation for acute exacerbation of COPD. Liu et al. [33] retrospectively studied a cohort of 138 patients with COPD requiring invasive mechanical ventilation for acute respiratory failure. The cause of acute respiratory failure was acute exacerbation of COPD in $55 \%$ and pneumonia in $44 \%$ of patients. The hospital mortality rate was $39.9 \%$ in all patients and $31.1 \%$ in the acute exacerbation of COPD subgroup. Respiratory acidosis was corrected ( $\mathrm{pH}>7.30$ ) in $69.9 \%$ of survivors but only in $21.8 \%$ of non-survivors.

In a recent study, 205 consecutive patients hospitalized with acute exacerbation of COPD were followed prospectively for 3 years [31]. The in-hospital mortality rate was $8.3 \%$. The overall 6 -month mortality was $24 \%$, with 1-, 2-, and 3-year mortality rates of $33 \%, 39 \%$, and $49 \%$, respectively. More severe gas exchange abnormalities and longer hospital stays were associated with the hospital mortalities. Long-term mortality was associated with longer disease duration, lower serum albumin, low body mass index, and lower $\mathrm{PaO}_{2}$. MOF and sepsis were the most common immediate causes of death in patients with acute exacerbation of COPD admitted to the ICU. In another prospective study of 250 patients with acute exacerbation of COPD [34], invasive mechanical ventilation was started in $60 \%$ and NIV was tried in $40 \%$ of patients and was successful in $54 \%$ of them. Median duration of ventilation was 6 days. After several clinical trials reported improved outcomes [35], NIV has become the principal initial mode for providing mechanical ventilation to patients with acute exacerbation of COPD [36]. Since the indications for NIV are more liberal than those of invasive ventilation, it is difficult to directly compare the outcomes of mechanically ventilated patients treated with the two modes. In a study by Girou et al., however, adjusted odds of death $(0.37 ; 95 \%$ confidence interval [CI], 0.18-0.78) suggested that the mortality in patients with similar severity of illness treated with NIV was significantly lower.

\section{Asthma}

Severe status asthmaticus is a rare cause of acute respiratory failure requiring mechanical ventilation ( $1.5 \%$ of patients in the international cohort study) [4]. Patients in status asthmaticus who require invasive mechanical ventilation are at high risk of severe complications (pneumothorax, cardiopulmonary arrest) and mortality. Afessa et al. reported the incidence and outcomes of status asthmaticus in a US inner city hospital, from 1995 to 1998 [37]. Forty-eight out of 132 hospital admissions required mechanical ventilation $(36 \%)$. Mechanically ventilated patients had significant mortality $(21 \%)$ and high complication rates. Sixteen patients developed non-pulmonary organ failure and four developed pneumothorax requiring chest tube drainage. Interestingly, all patients who died in this study were female. 


\section{Pneumonia}

Pneumonia is a common cause of hypoxemic acute respiratory failure. Approximately $14-23 \%$ of acute respiratory failure episodes requiring mechanical ventilation are due to pneumonia. ICU mortality rates from acute respiratory failure due to pneumonia range from $37-44 \%[1,2,4,38]$. In many patients with pneumonia, however, complications such as septic shock and ALI, or acute worsening of underlying chronic lung disease (COPD) are the principal reasons for instituting mechanical ventilation. Compared to other ALI risk factors, pneumonia is associated with higher mortality (see ALI paragraph above).

\section{Interstitial Lung Diseases}

The majority of patients with interstitial lung disease and acute respiratory failure admitted to the ICU require invasive mechanical ventilation. Interstitial lung disease is, however, an uncommon cause of acute respiratory failure (less than $2 \%$ of patients in the international cohort study [4]). In a retrospective review [39] of 75 patients with interstitial lung disease who were mechanically ventilated at Mayo Clinic from 2003 to 2005 , acute respiratory failure was the most common cause of ICU admission (77\%), followed by sepsis (11\%) and cardiopulmonary arrest (4\%). Seventeen patients were initially treated with NIV but eventually all patients required invasive mechanical ventilation. Hospital mortality was $49 \%$. Patients with idiopathic pulmonary fibrosis tended to have a higher mortality rate than non-idiopathic pulmonary fibrosis forms of interstitial lung disease. Conventional lung protective mechanical ventilation was not associated with improved outcome. Worsening hypoxemia and higher positive end-expiratory pressure (PEEP) settings were associated with increased mortality. In an earlier study, Saydain and coworkers observed the clinical course of 38 patients with idiopathic pulmonary fibrosis admitted to the ICU. Acute respiratory failure was the most common reason for ICU admission. While $49 \%$ of the patients survived to hospital discharge, 12 of 13 survivors $(92 \%)$ died within 2 months after hospital discharge [40].

\section{Neuromuscular Diseases}

Patients with neuromuscular disease are frequently treated with both acute and chronic mechanical ventilation. Neuromuscular disease accounted for $2 \%$ of patients receiving mechanical ventilation in the international cohort study [4]. Compared to other causes of acute respiratory failure, patients with neuromuscular disease had higher costs and length of ICU stay and $68 \%$ required tracheostomy [4]. Hospital mortality was $15 \%$. Epidemiologic studies looking at the outcomes of acute respiratory failure due to specific forms of neuromuscular disease are scarce. Recently, Ali et al. [41] reported on the outcomes of 54 patients with Guillain-Barré syndrome who required mechanical ventilation. All but six patients $(89 \%)$ required tracheostomy. Forty-six patients $(85 \%)$ survived to hospital discharge, and 39 (72\%) were alive at the 1-year follow-up

\section{Trauma}

According to the international cohort study [4], in $7.3 \%$ of patients mechanical ventilation was employed because of trauma. Hospital mortality for these patients was 
$20 \%$. In a retrospective incident study of acute respiratory failure in the USA [3], acute respiratory failure related to trauma was more common in the younger age group and trauma without MOF was associated with a very low mortality rate. In a Scandinavian study, approximately $9 \%$ of cases of acute respiratory failure were caused by trauma [2]. Of the 508 cases of acute respiratory failure in the Berlin study, 19 were due to trauma with mortality of $20 \%$ [1]. Complicating coma, shock, and ALI are common indications for mechanical ventilation in patients with trauma. About $8-15 \%$ of cases of ALI are related to trauma $[2,4,15]$ with mortality lower than that for other ALI risk factors ( $24 \%$, see above) [15].

\section{Shock}

Shock is characterized by global hypoperfusion leading to lactic acidosis, hyperventilation and hypoperfusion of respiratory muscles, resulting in type IV respiratory failure. Up to $30 \%$ of oxygen consumption in shock may be used by the respiratory muscles contributing to a global imbalance between oxygen delivery and consumption. Pulmonary edema, ALI, and anemia often contribute towards respiratory distress. Work of breathing may ultimately overcome respiratory reserve leading to the development of acute respiratory failure. Early use of mechanical ventilation in severe shock may be justified to limit the work of breathing and decrease oxygen consumption by respiratory muscles. Septic shock, in particular, is commonly associated with acute respiratory failure and ALI. In the international cohort study, septic shock was a primary indication for mechanical ventilation in $9 \%$ of patients with mortality of $55 \%[4]$.

\section{Coma}

Coma is a non-specific syndrome of widespread central nervous system impairment resulting from various metabolic and structural etiologies. It usually results in type II respiratory failure due to upper airway dysfunction and hypoventilation. Intubation and invasive mechanical ventilation are usually required to protect the airway and maintain gas exchange. In the study by Esteban et al. [4], $16 \%$ of patients required mechanical ventilation because of coma. Reported ICU mortality was $36 \%$ in patients with coma who received mechanical ventilation.

\section{Conclusion and Future Considerations}

Advances in mechanical ventilation have dramatically changed the management and outcome of patients with acute respiratory failure. With increased access to mechanical ventilation, the burden of acute respiratory failure may grow beyond the health care budget of even the richest societies. Inconsistent use of standardized definitions for acute respiratory failure and, in particular, indications for mechanical ventilation, present the major impediment to the meaningful understanding of clinical research results and will have to be overcome in future studies. Population studies are needed to determine the risk factors, prevalence, and the attributable outcomes of various forms of acute respiratory failure in the community. Such studies will help identify the best strategies for the prevention and treatment of acute respiratory failure, will pinpoint important uncertainties that need to be tested in clinical trials, and will allow informed decisions regarding allocation of scarce resources so 
that bedside practitioners may best improve the quality-adjusted survival of their patients.

\section{References}

1. Lewandowski K, Metz J, Deutschmann C, et al (1995) Incidence, severity, and mortality of acute respiratory failure in Berlin, Germany. Am J Respir Crit Care Med 151:1121-1125.

2. Luhr OR, Antonsen K, Karlsson M, et al (1999) Incidence and mortality after acute respiratory failure and acute respiratory distress syndrome in Sweden, Denmark, and Iceland. The ARF Study Group. Am J Respir Crit Care Med 159:1849-1861

3. Behrendt CE (2000) Acute respiratory failure in the United States: incidence and 31-day survival. Chest 118:1100-1105

4. Esteban A, Anzueto A, Frutos F, et al (2002) Characteristics and outcomes in adult patients receiving mechanical ventilation: a 28-day international study. JAMA 287:345-355

5. Vincent JL, Sakr Y, Ranieri VM (2003) Epidemiology and outcome of acute respiratory failure in intensive care unit patients. Crit Care Med 31 (suppl 4):S296-299

6. Flaatten $H$, Gjerde $S$, Guttormsen $A B$, et al (2003) Outcome after acute respiratory failure is more dependent on dysfunction in other vital organs than on the severity of the respiratory failure. Crit Care 7:R72

7. Vincent JL, Akca S, De Mendonca A, et al (2002) The epidemiology of acute respiratory failure in critically ill patients. Chest 121:1602-1609

8. Doyle RL, Szaflarski N, Modin GW, Wiener-Kronish JP, Matthay MA (1995) Identification of patients with acute lung injury. Predictors of mortality. Am J Respir Crit Care Med $152: 1818-1824$

9. Suchyta MR, Orme JF, Jr., Morris AH (2003) The changing face of organ failure in ARDS. Chest 124:1871-1879

10. Ashbaugh DG, Bigelow DB, Petty TL, Levine BE (1967) Acute respiratory distress in adults. Lancet 2:319-323

11. Bernard GR, Artigas A, Brigham KL, et al (1994) The American-European Consensus Conference on ARDS. Definitions, mechanisms, relevant outcomes, and clinical trial coordination. Am J Respir Crit Care Med 149:818-824

12. Hughes M, MacKirdy FN, Ross J, Norrie J, Grant IS (2003) Acute respiratory distress syndrome: an audit of incidence and outcome in Scottish intensive care units. Anaesthesia $58: 838-845$

13. Bersten $A D$, Edibam $C$, Hunt $T$, Moran $J(2002)$ Incidence and mortality of acute lung injury and the acute respiratory distress syndrome in three Australian States. Am J Respir Crit Care Med 165:443 - 448

14. Goss CH, Brower RG, Hudson LD, Rubenfeld GD (2003) Incidence of acute lung injury in the United States. Crit Care Med 31:1607-1611

15. Rubenfeld GD, Caldwell E, Peabody E, et al (2005) Incidence and outcomes of acute lung injury. N Engl J Med 353:1685-1693

16. The Acute Respiratory Distress Syndrome Network. (2000) Ventilation with lower tidal volumes as compared with traditional tidal volumes for acute lung injury and the acute respiratory distress syndrome. N Engl J Med 342:1301 - 1308

17. Zilberberg MD, Epstein SK (1998) Acute lung injury in the medical ICU: comorbid conditions, age, etiology, and hospital outcome. Am J Respir Crit Care Med 157:1159-1164

18. Stauffer JL, Fayter NA, Graves B, Cromb M, Lynch JC, Goebel P (1993) Survival following mechanical ventilation for acute respiratory failure in adult men. Chest 104:1222-1229

19. Kraus PA, Lipman J, Lee CC, et al (1993) Acute lung injury at Baragwanath ICU. An eightmonth audit and call for consensus for other organ failure in the adult respiratory distress syndrome. Chest 103:1832-1836

20. Squara P, Dhainaut JF, Artigas A, Carlet J (1998) Hemodynamic profile in severe ARDS: results of the European Collaborative ARDS Study. Intensive Care Med 24:1018-1028

21. Monchi M, Bellenfant F, Cariou A, et al (1998) Early predictive factors of survival in the acute respiratory distress syndrome. A multivariate analysis. Am J Respir Crit Care Med 158: $1076-1081$ 
22. Peters SG, Meadows JA, 3rd, Gracey DR (1988) Outcome of respiratory failure in hematologic malignancy. Chest 94:99-102

23. Yilmaz M, Iscimen R, Keegan MT, et al (2007) Six-month survival of patients with acute lung injury: Prospective cohort study. Crit Care Med 35:2303-2307

24. Montgomery AB, Stager MA, Carrico CJ, Hudson LD (1985) Causes of mortality in patients with the adult respiratory distress syndrome. Am Rev Respir Dis 132:485-489

25. Ferring M, Vincent JL (1997) Is outcome from ARDS related to the severity of respiratory failure? Eur Respir J 10(6):1297-1300

26. Hopkins RO, Weaver LK, Pope D, Orme JF, Bigler ED, Larson LV (1999) Neuropsychological sequelae and impaired health status in survivors of severe acute respiratory distress syndrome. Am J Respir Crit Care Med 160:50-56

27. Herridge MS, Cheung AM, Tansey CM, et al (2003) One-year outcomes in survivors of the acute respiratory distress syndrome. $\mathrm{N}$ Engl J Med 348:683-693

28. Schelling G, Stoll C, Haller M, et al (1998) Health-related quality of life and posttraumatic stress disorder in survivors of the acute respiratory distress syndrome. Crit Care Med 26: $651-659$

29. Esteban A, Anzueto A, Alia I, et al (2000) How is mechanical ventilation employed in the intensive care unit? An international utilization review. Am J Respir Crit Care Med 161: $1450-1458$

30. Masip J, Roque M, Sanchez B, Fernandez R, Subirana M, Exposito JA (2005) Noninvasive ventilation in acute cardiogenic pulmonary edema: systematic review and meta-analysis. JAMA 294:3124-3130

31. Gunen H, Hacievliyagil SS, Kosar F, et al (2005) Factors affecting survival of hospitalized patients with COPD. Eur Respir J 26:234-241

32. Seneff MG, Wagner DP, Wagner RP, Zimmerman JE, Knaus WA (1995) Hospital and 1-year survival of patients admitted to intensive care units with acute exacerbation of chronic obstructive pulmonary disease. JAMA 274:1852-1857

33. Liu H, Zhang TT, Ye J (2007) Analysis of risk factors for hospital mortality in patients with chronic obstructive pulmonary diseases requiring invasive mechanical ventilation. Chin Med J (Engl ) 120:287-293

34. Afessa B, Morales IJ, Scanlon PD, Peters SG (2002) Prognostic factors, clinical course, and hospital outcome of patients with chronic obstructive pulmonary disease admitted to an intensive care unit for acute respiratory failure. Crit Care Med 30:1610-1615

35. Ram FS, Picot J, Lightowler J, Wedzicha JA (2004) Non-invasive positive pressure ventilation for treatment of respiratory failure due to exacerbations of chronic obstructive pulmonary disease. Cochrane Database Syst Rev CD004104

36. Girou E, Brun-Buisson C, Taille S, Lemaire F, Brochard L (2003) Secular trends in nosocomial infections and mortality associated with noninvasive ventilation in patients with exacerbation of COPD and pulmonary edema. JAMA 290:2985-2991

37. Afessa B, Morales I, Cury JD (2001) Clinical course and outcome of patients admitted to an ICU for status asthmaticus. Chest 120:1616-1621

38. Vasilyev S, Schaap RN, Mortensen JD (1995) Hospital survival rates of patients with acute respiratory failure in modern respiratory intensive care units. An international, multicenter, prospective survey. Chest 107:1083-1088

39. Fernandez-Perez ER, Tenad H, Daniels CE, Ryn TH, Gajic O (2006) Ventilator settings and outcome in patients with interstitial lung disease requiring mechanical ventilation in the intensive care unit. Chest 130:152s (abst)

40. Saydain G, Islam A, Afessa B, Ryu JH, Scott JP, Peters SG (2002) Outcome of patients with idiopathic pulmonary fibrosis admitted to the intensive care unit. Am J Respir Crit Care Med $166: 839-842$

41. Ali MI, Fernandez-Perez ER, Pendern S, Brown DR, Wijdicks EF, Gajic O (2006) Mechanical ventilation in patients with Guillain-Barre Syndrome. Respir Care 51:1403-1407 